

1. 緒言

石炭は地球上で最も豊富に存在し安価な炭素源であ るので, 将来人類は好むと好まざるにかかわらず石炭 を使用せざるを得なくなるであろら。石炭の利用法の 中でガス化を考えると, 燃料用のガスを製造するエネ ルギーとしての利用と, メタノールや $\mathrm{C}_{1}$ 化学などを 対象にした合成原料としての利用に大別することがで きる。しかし石炭利用の経済性を考えるとどうしても スケールメリットをだす必要があり, 単位プラントの 石炭処理能力は 1 万 $\mathrm{t} / \mathrm{d}$ 以上の大規模なプラントが要 求される。したがって生産規模の小さい $\mathrm{C}_{1}$ 化学など の原料には必ずしも適せず, 燃料ガス, 燃料用メタノ 一ル，間接液化による燃料油製造など，大量の石炭を 集中処理しなければならない工業が 対象になってく るものと思われる。

このように考觉ると, 石炭ガス化の将来は合成ガス の製造が非常に重要になるので，ガス化技術としては 必然的に高温化を指向することになり, 高温ガス化炉 の開発が主流になるものと思われる。

これらのことから, 今後のガス化炉は高温化に伴う 種々の問題について対策しなければならなくなるが, 本章ではその手始めとして高温ガス化炉内に拈ける石 炭灰分の挙動に注目し，考察と検討とを試みた。

\section{2. 従来の石炭分類の盲点}

従来の石炭の分類は, 石炭中の炭素質にのみ注目し て行われてきた。たとえば石炭化度を基準にした亜 炭, 褐炭, 歴青炭, コーキング性を基準にした弱粘結炭, 粘結炭, 強粘結炭, あるいは石炭の組織を基準にした 輝炭, 暗炭, 木質炭母, などである。これらの分類では 石炭中の灰分は，水分と同様 dry ash free (d.a.f) 基準としてまったく無視されている。

* 工学部 小金井市中町 2 の 24 の 16

** 技術研究所 川崎市川崎区南渡田町 1 の 1

$\begin{array}{lllll}\text { 東京農工大学* } & \text { 平 } & \text { 戸 } & \text { 瑞 } & \text { 穂 } \\ \text { 日 本 鋼 管(姝** } & \text { 鈴 } & \text { 木 } & \text { 明 } & \text { 夫 } \\ \text { 東京農工大学* } & \text { 二 } & \text { 宮 } & \text { 善 } & \text { 彦 }\end{array}$

これは従来の石炭が乾留, 燃焼等灰分と直接関係し ないか，あるいは避けて通り得る分野を中心に使用さ れてきたためである。しかし今後石炭の完全ガス化を 指向するような高温下での石炭処理を考えると，石炭 中の灰分の挙動は炭素質の構造以上に重要になってく る。たとえば $1,200^{\circ} \mathrm{C}$ をこえる高温ガス化では，炭素 質部分の反応速度はきわめて速くなり，ガス化反応は 瞬時に化学平衡状態に到達するので, 反応上の問題は あまり起こらない。しかし $1,200^{\circ} \mathrm{C}$ をこえる高温下で は，石炭中の灰分の一部は溶融し始めるので，灰分の 高温挙動を予測し，適切な対策と処理の施してある炉 でなければ，正常な連続操作はできない。すなわち高 温ガス化では，反応よりも灰分の処理がより重要にな ってくる。したがって今後工業化を指向した高温ガス 化炉の開発は灰分の高温挙動を熟知したうえで進める ことが大切であり，このためには石炭中の灰分の性質 を考慮した新らしい石炭の分類が必要になってくる。 灰分を考慮した石炭ガス化用の新しい分類を提唱する 所以である。

\section{3. 石炭高温ガス化の問題点}

石炭を高温度でガス化する場合，ガス化炉内では二 つの温度が問題になる。ガス化反応温度と, ガス化炉 操作温度である。

(1) ガス化反応温度

$1,000^{\circ} \mathrm{C}$ 以上の高温になると，石炭のガス化は生成 チャーの水性ガス化反応が律速になるが，この反応の 反応速度は $1,000^{\circ} \mathrm{C}$ をこえると非常に速くなり，瞬時 に平衡状態に達して一定組成のガスを生成する。しか も圧力により変化するが, $1,200^{\circ} \mathrm{C}$ 前後になるとガス 中の水蒸気はすべてカーボンと反応して存在し得なく なるため，これ以上温度を上げても反応にはまったく 関係せず，ガス組成も飽和に達し一定組成となる。

図 1 は 1，20，100bar の圧力下に和けるカーボン 


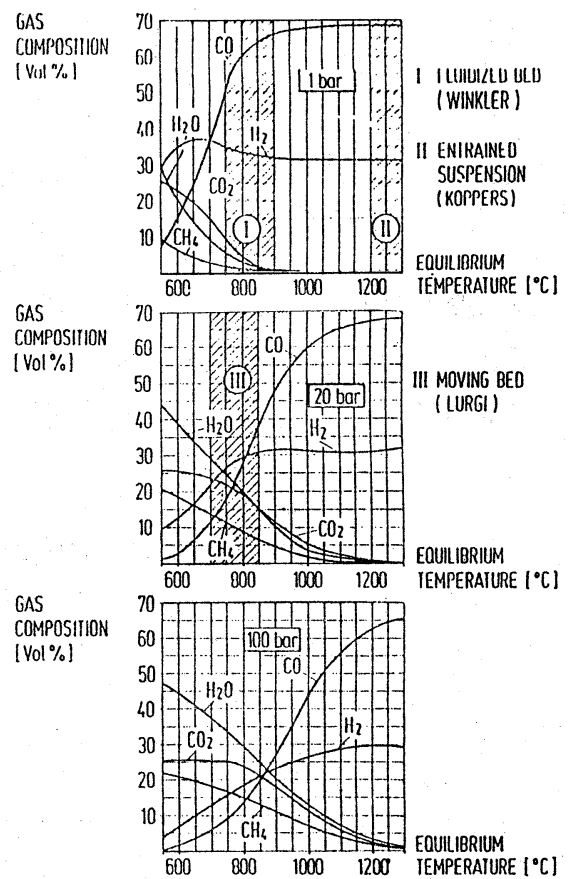

図 1 反応温度と平衡ガス組成

・水蒸気反応の反応温度とガス組成との関係を示した もので'), 1 bar の場合 $900^{\circ} \mathrm{C}$ 以上, 100bar の場 合 $1,300^{\circ} \mathrm{C}$ 以上になると水蒸気は瞬時に反応しつくされ て 0 となり，ガス組成は $\mathrm{CO}$ と $\mathrm{H}_{2}$ のみでその比率も 一定になる。

図 2 はこの飽和状態に到達したガス化温度を, ガス化圧力の関数として示したものである。両者 の関係は直線で示されるが，この温度が各圧力に 対する最適ガス化反応温度であり，この線より上 の領域でガス化反応を進めると，ガス組成は変化 しないにかかわらずガスの系外に持出す顕熱は増 大するので，ガス化炉の熱効率は低下する結果に なる。

(2) ガス化炉操作温度

ガス化炬操作温度は，使用する石炭中の灰分の 性質で決められる。固定層炉や流動層炬などのよ らに灰分を固体でガス化炉から抜出すDry ash 方式の炉では，炉内に扣けるクリンカーの生成を 防ぐため灰分の軟化点 以下で操業する必要があ り，噴流層炉，溶融層炉などのように灰分を流動 状態で抜出す Wet ash 方式の炉では, 溶融スラ ッグの円滑な流れをたすけるため流動点以上での 高温操作が必要となる。

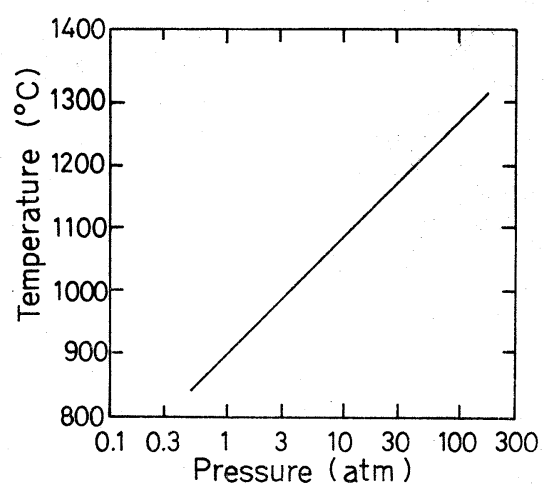

図 2 ガス化炉圧力と最適ガス化反応温度

このようにガス化炉の操作温度は死分の融点に左右 され，任意に設定することはでさない。

ガス化炉ではこの二つの温度，すなわち最適ガス化 反応温度とガス化炉操作温度とが一致したとき最高の 効率が得られるので，この三つの温度をできるだけ接 近させることが大切である。

現在 Dry ash 方式のガス化炉では，灰分の制約を らけて $1,000^{\circ} \mathrm{C}$ 以下と軟化点よりかなり低い温度領域 で操業しているが，反応上からは当然最適ガス化反応 温度まで上げて操業すべきである。また Wet ash 方 式のガス化炉では現在 $1,500^{\circ} \mathrm{C}$ 以上と流動点以上の高 温でガス化しているが，これは最適ガス化反応温度ま で下げて操業することが望ましい。最も効率の高いが ス化炬とは，最適ガス化反応温度で，安定した連続操

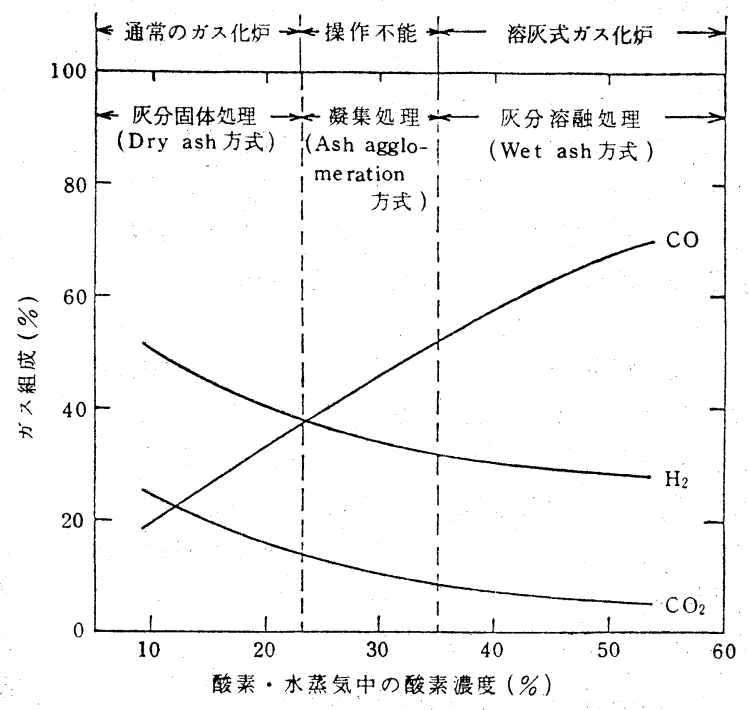

図 3 酸素濃度とガス組成および炉内灰分の処理方式 
業のできるガス化炉である。

図 3 はガス化炉に供給する酸素濃度と生成ガス組成 および適用ガス化炉の分類を示したものである2゙。酸 素濃度を基準にした理由は, 局部過熱を加味したガス 化炉内の最高温度を表現したものと推察されるが，通 常の Dry ash 方式のガス化炉では使用できる酸素濃 度は $24 \%$ 以下，酸素濃度 $35 \%$ 以上は Wet ash 方式に なることを指摘している。筆者はこれらの值を流動層 および噴流層ガス化炉の基礎実験装置で確認したが,

溶融点 $1,300^{\circ} \mathrm{C}$ 前後の石炭を使用した場合ほほ成立 し，妥当な分類であった。な㫏素濃度24～35\%は操 作不能領域に分類されているが, 現在ではAsh agglomeration 方式のガス化炉としてこの領域でも操作で きるようになっている。

\section{4. 石炭中の灰分について}

石炭中の灰分は，原料の植物中に含まれていた無機

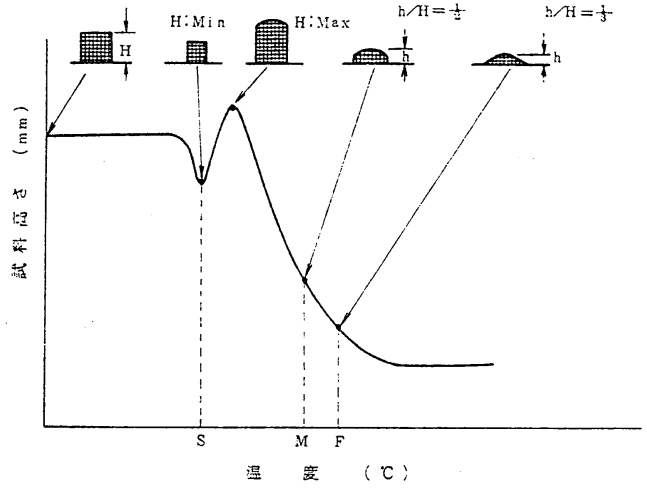

$\mathrm{S}$ ：軟化点, $\mathrm{M}$ ：溶融点, $\mathrm{F}$ ：流動点

図 4 高温顕微鏡による石炭灰の高温挙動観察

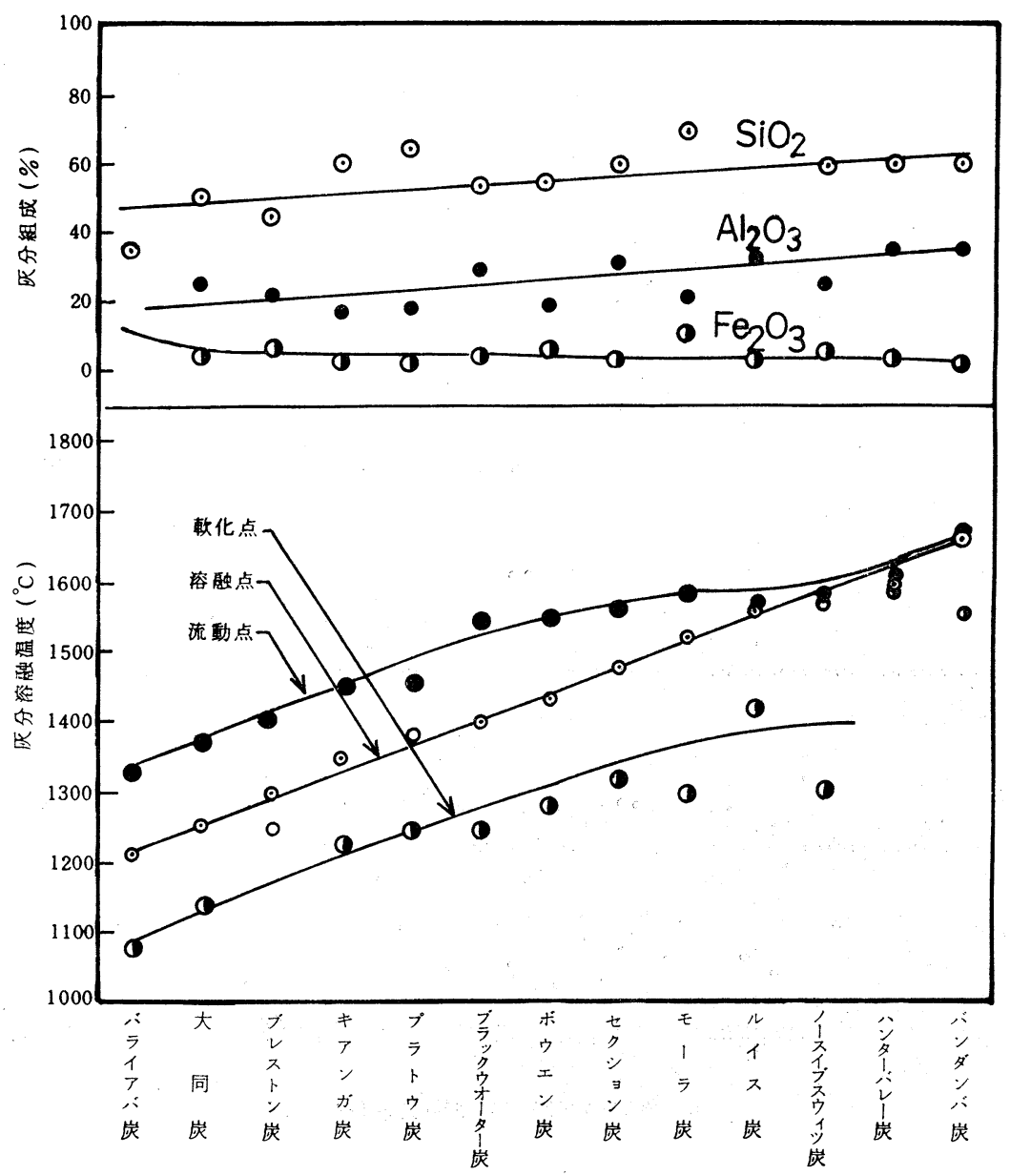

図 5 石炭中の灰分の組成と灰分溶融温度 


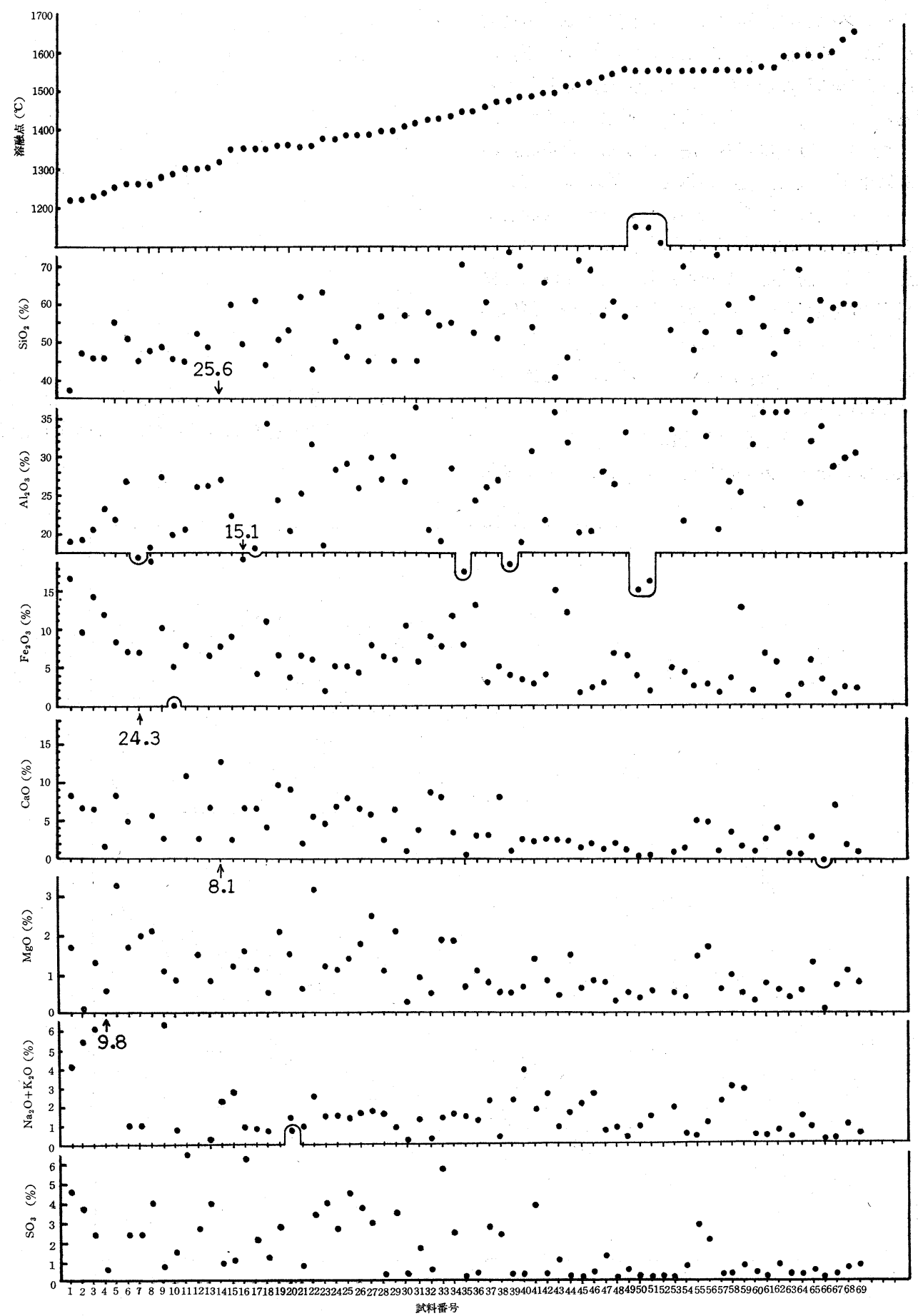

図 6 世界の石炭灰の溶融点と化学組成 
成分, 植物が運搬, 堆積中に周囲より混入した土砂, 地中に埋蔵されてから地下水あるいは熱水により溶解 輸送された鉱物質，などに起因しているので，産炭地・ によってその組成は大幅に変り千差万別であるが，大 体次のような值である3)。

酸性成分（灰分の融点を上げる成分）

$$
\begin{array}{lll}
\mathrm{SiO}_{2} & : 40 & \sim 60 \mathrm{wt} \% \\
\mathrm{Al}_{2} \mathrm{O}_{3} & : 15 & \sim 35 "
\end{array}
$$

塩基性成分（灰分の融点を下げる成分）

$\begin{array}{lll}\mathrm{Fe}_{2} \mathrm{O}_{3} & : 5 \sim 25 \mathrm{wt} \% \\ \mathrm{CaO} & : 11 \sim 15 " \\ \mathrm{MgO} & : 0.5 \sim 8 " \\ \mathrm{Na}_{2} \mathrm{O}, \mathrm{K}_{2} \mathrm{O} & : 1 \sim 4 \prime \prime \\ \mathrm{SO}_{3} & : 1 \sim 20 "\end{array}$

灰分の融点は JIS-M8801-1972 により ゼーゲルューンを用いて測定されるが，高 温顕徽鏡を用いると容易に測定され，両者 の測定值はよく一致する4)5)。図 4 亿高温 顕微鏡により観察した灰分の高温挙動を 示す。 $3 \mathrm{~mm}$ 立方に成型した灰分試料の温 度を上げて行くと，S 点付近で粒子が局部 的に溶け始め粒子間の空間をうめるので試 料は収縮する。この点が軟化点である。軟 化点をすぎると熱膨張により体積は増大し 最大值を示すが，それ以上温度を上げると 試料は溶融しはじめ, 試料の高さは急速に 減少する。試料の高さが最初の半分になっ た点を溶融点, $1 / 3$ にった点が流動点であ る。

高温下における灰分は雰囲気ガスにより 化合物の形が変るので, 各融点も変化す る。一般に酸性ガス雾囲気下に括ける融点 は，還元性雾囲気下に打ける值より 40〜 $170^{\circ} \mathrm{C}$ 高くなっている。

灰分の融点は(1)式で示される酸性率によ り傾向づけられ，酸性率が 1 前後であれば 溶融点は $1,200^{\circ} \mathrm{C}$ 前後と低く, 5 以上であ れば $1,350^{\circ} \mathrm{C}$ 以上の高温になることが報告 されている3゙。

$$
\text { 酸性率 }=\frac{\mathrm{SiO}_{2}+\mathrm{Al}_{2} \mathrm{O}_{3}}{\mathrm{Fe}_{2} \mathrm{O}_{3}+\mathrm{CaO}+\mathrm{MgO}}
$$

\section{5. 石炭の化学的組成と融点}

融点の異なる13種の石炭を溶融点の順序 に並べ，軟化点および流動点との相関を求
めてみると図 5 のようになる。すなわち $1,400^{\circ} \mathrm{C}$ 程度 までは軟化点, 流動点共に溶融点と同一挙動を示す が， $1,400^{\circ} \mathrm{C}$ を越ると軟化点は飽和状態の温度を示し, 流動点は溶融点に近づく傾向がみられる。

これは $1,400^{\circ} \mathrm{C}$ 前後の高温になると, 灰分中のほと んどの低融点化合物は溶け始めるため 軟化点は 1,400 ${ }^{\circ} \mathrm{C}$ 前後の同じ温度になり, かつ他の成分の溶融も急速 に起こるので, 溶融点と流動点の温度差があまりなく なってくるためである。

次に世界中で産出する69種類の石炭について還元性 雰囲気下に护る灰分を測定し, 産炭地, 石炭の種類 などに関係なく灰分の溶融点の順序に並べると, 図 6 のごとく $1,200 \sim 1,700^{\circ} \mathrm{C}$ の間に均等に分布しているこ とを示す直線関係が得られる。これは地球上には溶融

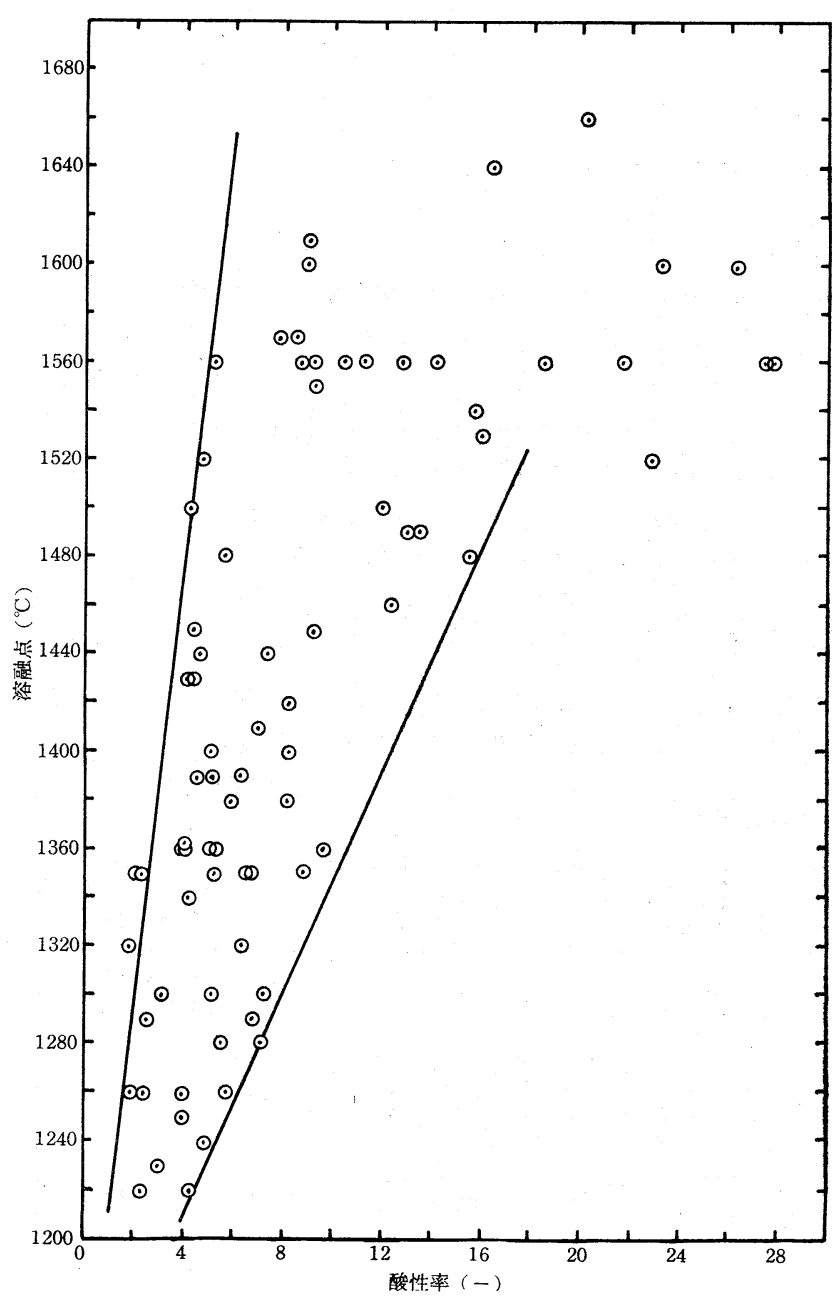

図 7 酸性率と溶麗点との関係 
点が $1,200^{\circ} \mathrm{C}$ 程度の低融点炭から, $1,700^{\circ} \mathrm{C}$ 程度の高融 点炭まで幅広く存在していることを示するので, 今後 のガス化技術は低融点炭対象の炉から高融点炭対象の 炉まで，幅広い領域で開発を進めなりればならない。 このような広範囲な融点をもつ石炭を効率よくガス化 するためには，灰分の高温挙動を解明し，各石炭の性 質に適合したがス化炉を選択することが重要である。

な怙米国炭は一般に低融点のものが多く, 豪州炭は 高融点のものが多い傾向が認められる。

灰分の化学的組成と溶融点との相関をみるため, 図 6 中に灰分中の $\mathrm{SiO}_{2}, \mathrm{Al}_{2} \mathrm{O}_{3}, \mathrm{Fe}_{2} \mathrm{O}_{3}, \mathrm{CaO}, \mathrm{MgO}$, $\left(\mathrm{Na}_{2} \mathrm{O}+\mathrm{K}_{2} \mathrm{O}\right), \mathrm{SO}_{3}$ の值を併記した。各成分ともか なりのばらつきがあり明確な相関はみられないが，酸 性成分量の増加は溶融点を上げ, 塩基性成分量の増加 は溶融点を下げている傾向は認められる。

これらの組成より灰分の酸性率を計算し溶融点との 相関を求めたのが図 7 である。酸性率は同一值であっ ても溶融点は広範囲に分布して和り, 明確な相関関係 は得られなかった。

\section{6. 石炭ガス化炉と炭種の組み合わせ}

前述したと扔り世界には低融点炭から高融点炭まで 幅広く分布しているが，これらの石炭をガス化する場 合，ガス化师との望ましい組み合わせについて考察す る。

図 8 は使用する石炭灰分の融点とガス化灿との理想 的組み合わせ，和よび最適化のための対策を示したも のである。Dry ash 方式のガス化炉では灭分を固体 のままで拔出すので, 使用する石炭は軟化点 $1,300^{\circ} \mathrm{C}$ （溶融点は $1,400^{\circ} \mathrm{C}$ ) 以上の高融点炭が望ましい。一方 Wet ash 方式のガス化炉では灰分を流体化して処理 するので, 使用する石炭は流動点 $1,400^{\circ} \mathrm{C}$ （溶融点 $1,300^{\circ} \mathrm{C}$ ) 以下の低融点炭が適している。溶融点が $1,300 \sim 1,400^{\circ} \mathrm{C}$ の範囲の石炭は, 工夫次第で Dry,

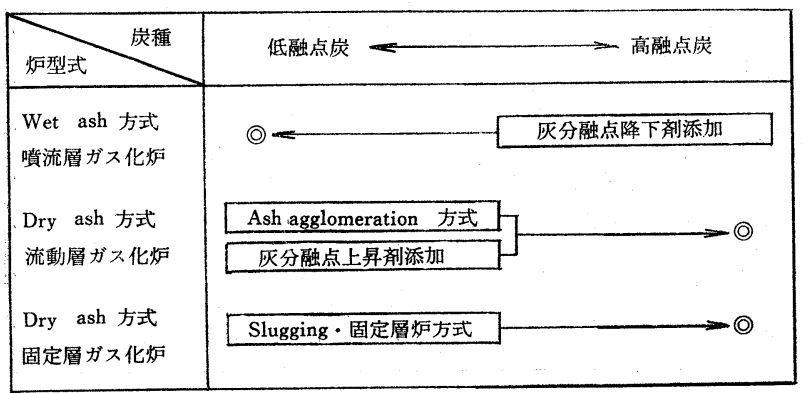

(ㅇ) 最適組み合わせ
図 8 石炭炭種とガス化炉の理想的組み合わせ
Wet，いずれの方式のガス化炉でる処理可能である し, Ash agglomeration 方式のガス化炉でもよい。 - ガス化师の効率を最大にするためには, 最適ガス化 反応温度と炉操作温度を一致させる必要があるが，噴 流層炉により高融点炭を処理しなければならない場合 には，適当なフラックスを添加して灰分の融点を下 げ，炉操作温度を下げて最適ガス化反応温度に近づけ ることができれば理想的である。

同様に流動層炉で低融点炭をガス化する場合には， 適当なフラックスの添加により灰分の融点を上げ，炉 操作温度を最適ガス化反応温度に近づけるか, あるい は灰分の軟化点まで操作温度を上げ，灰分を粗粒化し て炉外に抜出す Ash agglomeration 方式にすること が望をしい。

固定層炉で低融点炭を処理する場合, 最近炉底部に バーナーを付けて酸素を供給し, 灰分を溶融スラッグ 化してガス化温度を上げ，ガス化炉の効率向上を計っ た Slugging 固定層組久合わせ方式のガス化炉の開発 が進められているが6), これは前述した発想と同一で あり有効な手段である。

図 6 亿示した石炭の溶融点別の埋蔵量を推定する 之, $1,300^{\circ} \mathrm{C}$ 以下の低融点炭は米国炭を中心に世界可 採埋蔵量の約 $1 / 3,1,400^{\circ} \mathrm{C}$ 以上の高融点炭は豪州炭を 中心に同じく $1 / 3,1,300 \sim 1,400^{\circ} \mathrm{C}$ の中融点炭が $1 / 3$ と世 界中にほ注均衡して存在している。したがって将来の 石炭ガス化技術としてはDry ash 方式, Wet ash 方 式の両者の開発が必要となるであろう。

\section{7. 溶融スラッグの高温挙動}

石炭の灰分は種々の無機化合物の混合体であり, そ れぞれの成分は融点も異なるので, 溶融点付近では複 雑な挙動を示す。

図 9 はスラッグが溶融し始めてから流動する過程に 扣けるスラッグの粘性の変化状態を示したものであ る7)。スラッグは液相温度 $\mathrm{T}_{\mathrm{L}}$ 以上では均 一な溶融液相で存在するが，液相温度以下 では溶融スラッグ中に高沸点成分が固相と して析出して混相となり，スラリー状態に なっている。したがって液相温度 $\mathrm{T}_{\mathrm{L}}$ はス ラッグ中に固体結晶が共存しらる最高温度 となり, この温度以上に加熱して初めて均 一な液相になる。

液相温度以上の高温溶融スラッグを冷却 すると，液相温度に下ったところで固相 が析出し始めてスラリーとなり, 以後温度 の低下と共に析出固相が增加しつつ高濃度 


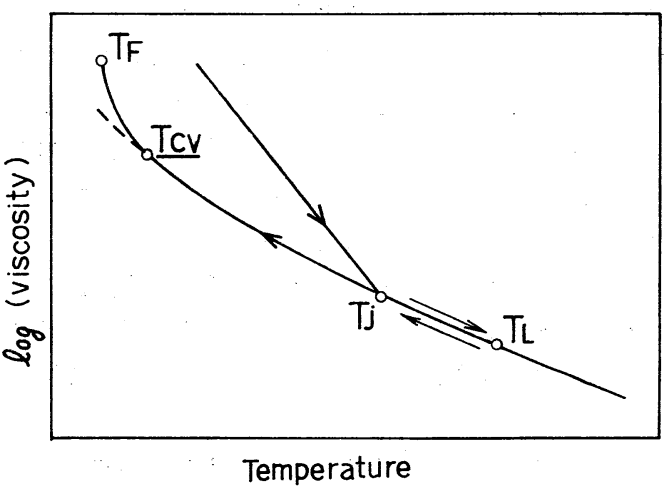

図 9 溶䗭スラッグの高温挙動

スラリーとなって臨界粘性温度 $T_{\mathrm{CV}}$ に達し，ここで 一度に固体結晶を析出して流動性を失うにいたる。 T F はスラッグが固化する凝結温度である。な掞スラ ッグを加熱溶解する場合の温度と粘度との関係は $\mathrm{T}_{\mathrm{F}}$ 〜 $\mathrm{T}_{\mathrm{CV}} \sim \mathrm{T}_{\mathrm{L}}$ の過程をたどらず， $\mathrm{T}_{\mathrm{H}} \sim \mathrm{T}_{\mathrm{J}} \sim \mathrm{T}_{\mathrm{L}}$ とな る。

Wet ash 方式のガス化炉では，炉内におけるスラ ッグの流動性をよくするため, スラッグは $\mathrm{T}_{\mathrm{L}}$ 以上の 温度になるよう制御されなければならない。しかし誤 操作などにより炉内温度が $\mathrm{T}_{\mathrm{CV}}$ にまで下がるとスラ ッグは固化し, 壁面に蓄積されて流路閉塞などの障害 の原因になるので，ガス化炉を操作する場合には，使 用する石炭の $T_{\mathrm{CV}}$ を測定し, 温度制御の限界を決め て炉内温度を一定限度以下に下げないよう配慮しなけ ればならない。

臨界粘性温度 $T_{\mathrm{CV}}$ は, スラッグ中に析出した固形
分の量，すなわちスラリー濃度に大きく影響されるた め灰分の組成によって決り, 均一な溶融状態のスラリ 一粘度とは直接関係しない。

臨界粘性温度 $T_{C V}$ は次の実験式で表される7。

$$
\begin{aligned}
& \mathrm{T}_{\mathrm{CV}}=-1,470(\mathrm{~S} / \mathrm{A})+360(\mathrm{~S} / \mathrm{A})^{2}-14.7 \\
& (\mathrm{~F}+\mathrm{C}+\mathrm{M})+0.15(\mathrm{~F}+\mathrm{C}+\mathrm{M})^{2} \\
& +2,990 \\
& \text { ここで } \mathrm{S}: \mathrm{SiO}_{2} \quad \mathrm{wt} \% \\
& \mathrm{~A}: \mathrm{Al}_{2} \mathrm{O}_{3} \text { " } \\
& \mathrm{F}: \mathrm{Fe}_{2} \mathrm{O}_{3} \text { " } \\
& \mathrm{C}: \mathrm{CaO} \text { " } \\
& \mathrm{M}: \mathrm{MgO} \text { " } \\
& \mathrm{S}+\mathrm{A}+\mathrm{F}+\mathrm{C}+\mathrm{M}=100
\end{aligned}
$$

である。

(2)式により計算される $T_{\mathrm{CV}}$ は，灰分の酸性成分, 塩 基性成分などの組成によって決り, 軟化点, 溶融点, 流動点等融点との対応はなされていない。図6で使用 した69種類の石炭試料について $T_{\mathrm{CV}}$ と灰分融点との 関係を調査したが，両者の間に明確な傾向は認められ

\begin{tabular}{|c|c|c|c|c|c|c|c|c|}
\hline 炭 & $\mathrm{SiO}_{2}$ & $\mathrm{Al}_{2} \mathrm{O}_{3}$ & $\mathrm{Fe}_{2} \mathrm{O}_{3}$ & $\mathrm{CaO}$ & $\mathrm{MgO}$ & $T_{C V}$ & 流動点 & 溶融点 \\
\hline Baraiaba & 37.3 & 24.0 & 16.8 & 8.4 & 1.7 & 1,296 & 1,330 & 1,220 \\
\hline Yarrabee & 45.7 & 23.4 & 12.0 & 1.4 & 0.6 & 1,319 & 1,340 & 1,240 \\
\hline Tangorin & 25.6 & 27.2 & 7.8 & 12.6 & 8.1 & 1,432 & 1,490 & 1,320 \\
\hline 大 同 & 49.5 & 15.1 & 19.4 & 6.7 & 1.6 & 1,346 & 1,390 & 1,350 \\
\hline Blackwater & 59.7 & 22.4 & 8.9 & 2.5 & 1.2 & 1,460 & 1,460 & 1,350 \\
\hline Liddll & 46.3 & 29.3 & 5.2 & 8.0 & 1.4 & 1,400 & 1,520 & 1,390 \\
\hline Borehole & 52.6 & 24.4 & 13.4 & 3.2 & 1.1 & 1,276 & 1,510 & 1,450 \\
\hline Callide & 40.7 & 36.1 & 15.4 & 2.4 & 0.4 & 1,568 & 1,550 & 1,500 \\
\hline Blair Athol & 62.4 & 31.7 & 2.0 & 1.1 & 0.3 & 1,439 & 1,600 & 1,560 \\
\hline Tarong & 60.6 & 33.9 & 3.4 & 0.1 & 0.1 & 1,507 & 1,600 & 1,600 \\
\hline Acland & 59.2 & 27.9 & 1.6 & 7.4 & 0.7 & 1,503 & 1,610 & 1,610 \\
\hline Rosewood & 60.3 & 29.9 & 2.4 & 2.0 & 1.1 & 1,479 & 1,600 & 1,640 \\
\hline
\end{tabular}
なかった。これらの中から12種類の石炭を選び，灰分 組成, $\mathrm{T}_{\mathrm{CV}}$ 計算結界, 溶融点, 流動点などを表 1 亿示 した。

次に液相温度 $T_{L}$ 以上の高温領域における均一な溶 融状態のスラッグの粘度について，J. D. Watt らは 次の実験式を提案している8 。

$$
\begin{aligned}
& \log (\text { poise })=\frac{\mathrm{m} \times 10^{7}}{(\mathrm{t}-150)^{2}}+\mathrm{C} \cdots \ldots . . . .(3) \\
& \text { ここで } \mathrm{t}: \text { スラッグ温度 }\left({ }^{\circ} \mathrm{C}\right) \\
& \mathrm{m}=0.0835 \mathrm{SiO}_{2}+0.00601 \mathrm{Al}_{2} \mathrm{O}_{3}-0.109
\end{aligned}
$$

表 1 各種石炭の臨界粘性温度

（註）各組成は wt \% , $\mathrm{T}_{\mathrm{CV}} \cdot$ 流動点・溶融点は ${ }^{\circ} \mathrm{C}$ 


$$
\begin{aligned}
\mathrm{c} & =0.0415 \mathrm{SiO}_{2}+0.0192 \mathrm{Al}_{2} \mathrm{O}_{3} \\
& +0.0276 \mathrm{Eq} . \mathrm{Fe}_{2} \mathrm{O}_{3}+0.016 \mathrm{CaO}-3.92
\end{aligned}
$$

$\mathrm{Eq} . \mathrm{Fe}_{2} \mathrm{O}_{3}=\mathrm{Fe}_{2} \mathrm{O}_{3}+1 \cdot 11 \mathrm{FeO}+1.43 \mathrm{Fe}$

$\mathrm{SiO}_{2}+\mathrm{Al}_{2} \mathrm{O}_{3}+\mathrm{Eq} . \mathrm{Fe}_{2} \mathrm{O}_{3}+\mathrm{CaO}+\mathrm{MgO}$

$$
=100
$$

である。

\section{8. 石炭灰の融点向上策：石炭灰の融点に対する $\mathrm{CaO}$ 添加の効果}

融点の低い石炭を流動層炉のような Dry'ash ガス 化炉で使用する場合, 何等かの方法で死分の融点を上 げ，最適ガス化反応温度に近い点でガス化炉を操作す ることが望ましい。

灰分の融点は組成によって一意的に決るので, 融点 もおのずと決ってしまう。しかし石炭に適当な添加剤 を加え，灰分の組成を人為的に変えれば，灰分の融点
を自由に操作することができるはずである。灰分の融 点を上げる成分は酸性成分の $\mathrm{SiO}_{2}, \mathrm{Al}_{2} \mathrm{O}_{3}$ などであ り，その影響は(1)式の酸性率によって示されている。 しかし高温の溶融点付近では灰分中の成分は共晶体を 形成し，融点は酸性率のよらな単純なものではなく, きわめて複雑な挙動を示している。

図10は $\mathrm{SiO}_{2}-\mathrm{Al}_{2} \mathrm{O}_{3}-\mathrm{CaO} 3$ 成分系の状態図であ る ${ }^{92}, \mathrm{SiO}_{2}, \mathrm{Al}_{2} \mathrm{O}_{3}, \mathrm{CaO}$ の 3 成分はそれぞれの温度 において独自の共晶体をつくり, 安定な状態を維持し ている。

3 成分中の $\mathrm{CaO}$ は塩基性成分であり，(1)式によれ ば灰分の融点を下げる効果があるといわれている。そ こで図10の状態図中にホスキン炭の灰分組成を挿入 し，その中の $\mathrm{CaO}$ 成分のみを増量した場合，灰分の 融点はどのように変化するかについて検討する。なお

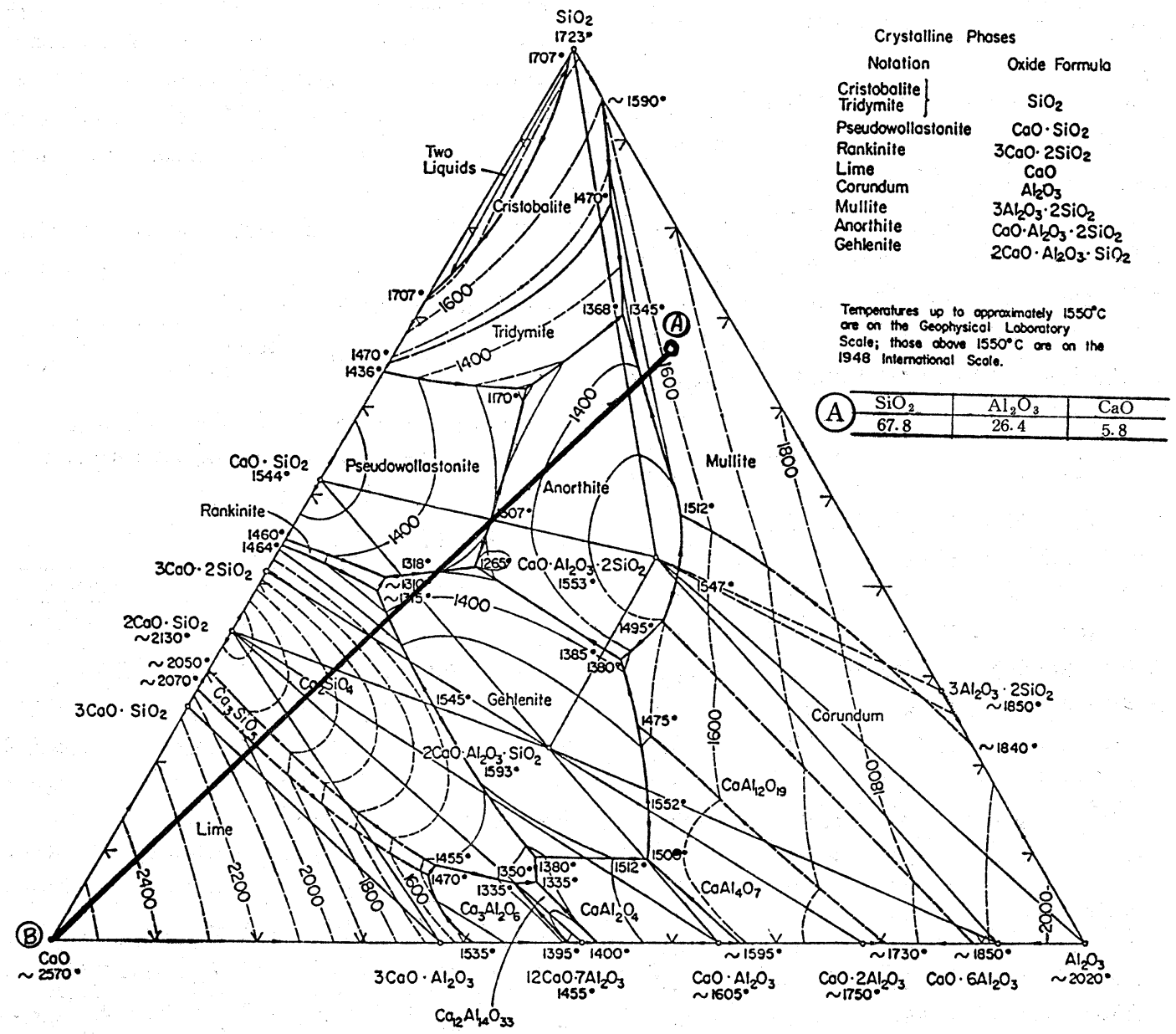

図10 $\mathrm{SiO}_{2} \cdot \mathrm{Al}_{2} \mathrm{O}_{3} \cdot \mathrm{CaO}_{3}$ 元状態図による $\mathrm{CaO}$ 添加の効果 


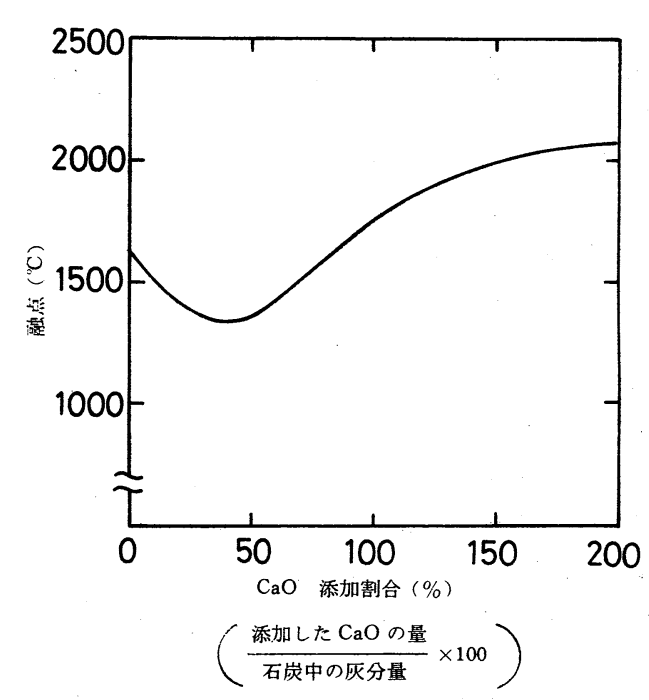

図11 $\mathrm{CaO}$ 添加による融点の変化

ホスキン炭の灰分は $\mathrm{SiO}_{2} 67.8 \mathrm{wt} \%, \mathrm{Al}_{2} \mathrm{O}_{3} 26.4 \mathrm{wt} \%$, $\mathrm{CaO} 5.8 \mathrm{wt} \%$ であり，図中(A)点で示される。

$\mathrm{CaO}$ を添加すると 3 成分系の融点は(A)点と $\mathrm{CaO} 100$ \%の (B)点とを結ぶ直線上を, B点に向って変化して行 く。(B)点は $\mathrm{CaO}$ の融点 $2,570^{\circ} \mathrm{C}$ である。

この図から $\mathrm{CaO}$ 量の変化と 3 成分系の融点との関 係を求めると図11のようになる。 $\mathrm{CaO} 38 \%$ の添加量 までは融点は下がり, 酸性率で示される結果に一致す るが，38\%をこえて $\mathrm{CaO}$ 量を増すと融点は急速に上 がり始め, $80 \%$ 添加で $\mathrm{CaO}$ 無添加の初期の融点をこ

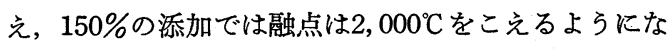
る。

石炭中の灰分，とくに $\mathrm{SiO}_{2}, \mathrm{Al}_{2} \mathrm{O}_{3}, \mathrm{CaO}$ などは ガス化過程で生成ガスに同伴される量は僅かであり, 大部分炉底部に残される。また上記 3 成分で灰分の 90 \%近くの值となるので，添加量として石炭中の灰分と ほぼ同量の $\mathrm{CaO}$ を加えれば,灰分の融点を上昇させ， 炉操作温度を最適ガス化反応温度に近づ得る可能性 は十分にあるものと思う。

西独の高温ウインクラーガス化炉では, 流動層ガス 化炉中に $\mathrm{CaO}$ の添加が報告されているが,これは $\mathrm{CaO}$ の添加量を増して灰分の融点を上げ，高温ガス 化をねらっているものと考えられる10)。

9. 溶融スラッグの粘度低減策：溶融スラッグに対す るフラックス添加の効果

J.D. Watt らは完全な溶融状態にあるスラッグ粘度 の推定に(3)式を提案したが，この式の精度を確認する ため近似した組成をもつ鉄鋼溶㳯の実測值と比較し

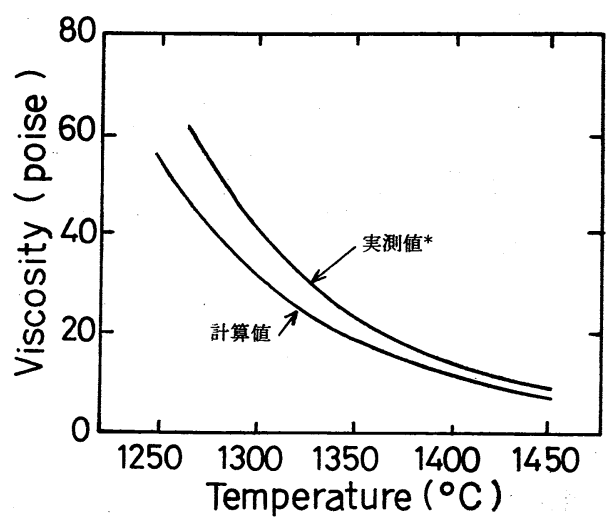

*溶鉄・溶㴖の物性便覧 日本鉄鋼協会(昭46)

図12 Watt の式による溶㳯粘度の計算値と 実測値との比較

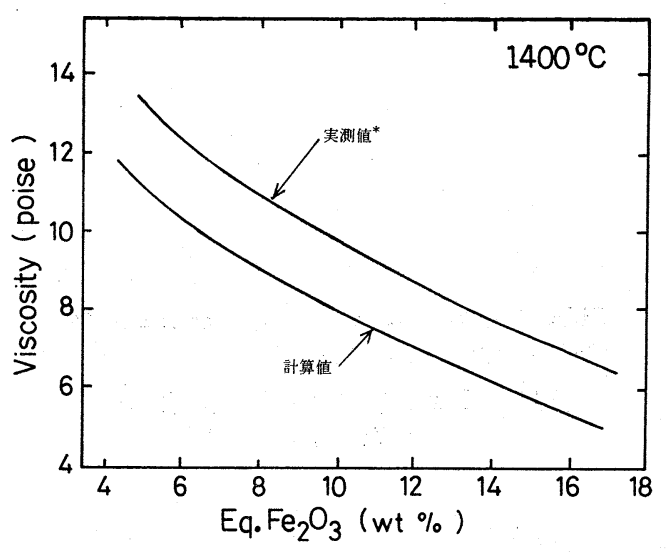

*溶鉄・溶涬の物性便覧 日本鉄鋼協会(昭46)

図13 Watt の式による溶涬粘度の計算と 実測值との比較

$た^{11)}$ 。

図12は死分の組成に近い $\mathrm{SiO}_{2} 43.06 \%, \mathrm{Al}_{2} \mathrm{O}_{3} 18.18$ $\%, \mathrm{Fe}_{2} \mathrm{O}_{3} 4.30 \%, \mathrm{CaO} 26.80 \%, \mathrm{MaO} 7.66 \%$ の組 成の鉄鋼溶涬の各温度における粘度の実測值と, 上記 組成より(3)式を用いて求めた粘度の計算值とを比較し たものである。また図13は上記溶涬中の $\mathrm{Fe}_{2} \mathrm{O}_{3}$ 量を変 化させた $1,400^{\circ} \mathrm{C}$ の溶㳯の粘度の実測值と，(3)式によ る計算值とを示したものである。

高温スラッグの粘度の測定は非常に難しい技術であ り，測定法によるばらつきも大きい。これらを勘案す ると，図12〜13に示された実測値と計算値はかなりよ く一致しているとみることができ，(3)式は溶融スラッ グの粘度計算に対し十分な精度をるつものと判断され る。 
さて噴流層のような Wet ash 方式のガス化炉の操 作を容易にするためには，溶融スラッグの粘度を低下 させる必要があり，高融点の石炭を使用する場合ガス 化师操作温度を上げなければならない。しかし最適ガ ス化反応温度をこ兄て炉操作温度を上げることは，ガ ス化炉の熱効率を低下させるばかりでなく，ガス化炉 耐火構造上も問題が多い。そこでJ.D.Wattらによる (3)式を用い，石炭中にフラックスを添加して灰分の組 成を変え, 溶融スラッグの粘度の低減について検討し

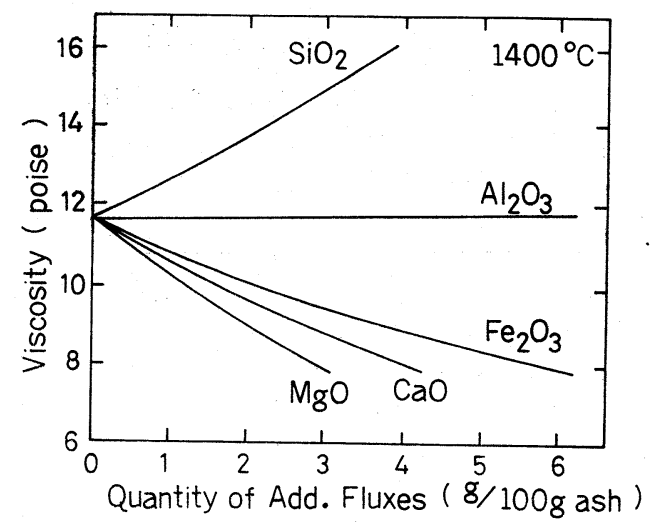

$\mathrm{SiO}_{2} 43.06 \%, \mathrm{Al}_{2} \mathrm{O}_{3} 18.18 \%, \mathrm{Fe}_{2} \mathrm{O}_{3} 4.30 \%$, $\mathrm{CaO} 26.80 \%, \mathrm{MgO} 7.66 \%$

図14 Flux 添加による粘度変化の推定 （Watt の式による）

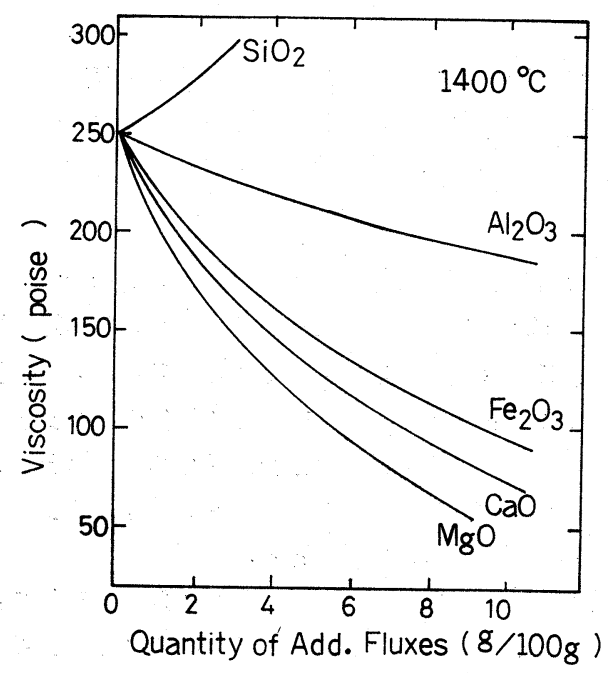

$\mathrm{SiO}_{2} 54.2 \%, \mathrm{Al}_{2} \mathrm{O}_{3} 26.1 \%, \mathrm{Fe}_{2} \mathrm{O}_{3} 7.1 \%$, $\mathrm{CaO} 10.4 \%, \mathrm{MgO} 2.2 \%$

図15 Flux 添加による粘度変化の推定 （Watt の式による）
た。

図14は $\mathrm{SiO}_{2} 43.06 \%, \mathrm{Al}_{2} \mathrm{O}_{3} 18.18 \%, \mathrm{Fe}_{2} \mathrm{O}_{3} 4.30$ $\%, \mathrm{CaO} 26.80 \%, \mathrm{MgO} 7.66 \%$ の組成をもつ死分 に各種のフラックスを添加し，(3)式により粘度の変化 を計算したものである。横軸のフラックス添加量は灰 分に対する割合であり，石炭に対する值とする場合に はこの值に灰分の割合をかける必要がある。

本計算例では $\mathrm{SiO}_{2}$ の添加はスラッグの粘度を上げ， $\mathrm{Al}_{2} \mathrm{O}_{3}$ は粘度にほとんど影響をあたえず, $\mathrm{Fe}_{2} \mathrm{O}_{3}$, $\mathrm{CaO}, \mathrm{MgO}$ はいずれもスラッグの粘度を急激に低下 させ，顕著なフラックス添加の効果が認められる。

図15は $\mathrm{SiO}_{2} 54.2 \%, \mathrm{Al}_{2} \mathrm{O}_{3} 26.1 \%, \mathrm{Fe}_{2} \mathrm{O}_{3} 7.1 \%$, $\mathrm{CaO} 10.4 \%, \mathrm{MgO} 2.2 \%$ の組成の灰分に, 各種フ ラックスを添加した場合のスラッグ粘度変化を示した ものである。

図14 と同様 $\mathrm{SiO}_{2}$ はスラッグの粘度を上げ， $\mathrm{Fe}_{2} \mathrm{O}_{3}$ ， $\mathrm{CaO}, \mathrm{MgO}$ はいずれも著しく粘度を下げているが, 本計算例の場合, $\mathrm{Al}_{2} \mathrm{O}_{3}$ も粘度を下げる作用をしてい： る。

以上の結果より明らかになったことは，溶融スラッ グの粘度を下げるフラックスとしては，灰分の融点を 下げる成分と同様塩基性の $\mathrm{Fe}_{2} \mathrm{O}_{3}, \mathrm{CaO}, \mathrm{MgO}$ の添 加が効果的である。一方，入手の容易さ，価格などか ら考えれば $\mathrm{Fe}_{2} \mathrm{O}_{3}, \mathrm{CaO}$ などが有利であり, 実用上 はこの 2 つに絞られるように思う。

\section{0. 高温ガス化に対する石炭炭種の対応}

現在のガス化炉の操作は炭種に固有の灰分の融点に よって操作温度が決められ, 最適ガス化反応温度は無 視されている。しかし将来の工業化に対しては当然高 効率のガス化が要求されるので，ガス化炬と炭種の最 適組み合わせ，あるいは石炭灰分の融点制御技術など す検討せざるを得なくなるであろう。

ガス化炉と炭種の組み合わせは，原則として流動層 などの Dry ash 方式のガス化炉には高融点炭, 噴流 層などのような Wet ash 方式の炬には低融点炭が適 している。

しかし溶融点 $1,300 \sim 1,400^{\circ} \mathrm{C}$ の中融点炭を処理する 場合や，ひとつの炉で処理する炭種を多様化すること も重要であり,このような場合には石炭にフラックス を添加し，灰分の融点を制御することも検討に值する と思ら。フラックスとしては融点を上げる場合の石灰 石，下げる場合の酸化鉄などが典型的な物 質である が，これ以外の物質についても検討する必要がある 5。

フラックスの添加はそのままコストアップにつなが 
るほか, 排出される灰分の量も増えるなど問題も多 い。しかしガス化恼の効率を向上させる有効な手段で あり, 将来は無視し得ない技術になると思ら。また石 炭の液化で使い捨ての鉄系触媒を用い, 液化残渣を噴 流層炉でガス化し水素を製造する場合などは，ガス化 に際しての融点低下が期待され, 最適ガス化反応温度 付近での効率のよいガス化を達成できる可能性が大き いように思う。

フラックスを添加する代りに多数の石炭の灰分を分 析し, 融点制御が可能な炭種を混炭して, 石炭灰分の 融点を目標值に近づけることも十分考えられる。石炭 は現在発熱量の調整のため混炭されているが，これを 灰分の融点制御のために混炭するわけで, 混合灰分の 挙動さえ明らかになれば技術的には十分可能である。

\section{1. 結言}

以上石炭の高温ガス化に関しガス化炉の性能を左右 する灰分について問題点の一端を述べた。将来石炭の ガス化が広く工業化されるためには, 高い効率と信頼 性をもった高温ガス化炉の開発が不可欠である。高効 率のガス化炬とは, 最適ガス化反応温度と炉操作温度 とが一致した場合で，これを実現するためには最適ガ ス化反応温度でガス化炉を運転できるよう, 石炭灰分 の融点を制御しなければならない。

灰分の融点制御はその石炭処理に適したガス化炉型
式の選定を原則とするが，他に石炭中に適当なフラッ クスを添加し, 融点やスラッグの粘度を变えることも 可能であり, 今後の研究が期待される。

\section{文献}

1) Rudolph, P. F. H., et al., EPRI WS-79-238, vol. 2, p. 22-1 (1981)

2）馬場有政, 本田英昌, 他, 石炭化学工業, （産業 因書) p.172（昭35）

3）燃料協会編，燃料便覧，（コロナ社） p.65（昭49）

4）木村英雄，燃協誌，36，75（昭32）

5) 大塚唯男, 矢田部照夫, 電力中央研究所技術研究 所報告, 化学57009 (昭33)

6) Sharman, R. B., et al., EPRI WS-79-238, vol. 2, p. 24-1 (1981)

7) Watt, J. D., et al., J. of the Inst. of Fuel, p.131 (April 1969)

8) Watt, J. D., et al., J. of the Inst. of Fuel, p.99 (March 1969)

9) Levin, E. M., et al., Phase diagrams for ceramists, Am. Ceramic Society (1974)

10) Adlhock, W., et al., EPRI WS-79-238, vol. 2, p. 29-1 (1981)

11）日本鉄鋼協会編，溶鉄・溶涬の物性便覧（昭46） 


\title{
The Behavior of Ash in the High Temperature Coal Gasification Reactor
}

\author{
Mituho HiRATo*, Akio SUZUKI**, Yoshihiko NinOMIYA* \\ $\left(\begin{array}{c}* \text { Department of Applied Chemistory for Resources, } \\ \text { Tokyo University of Agriculture and Technology } \\ * * \text { Technical Research Center, NIPPON KOKAN K. K }\end{array}\right)$
}

SYNOPSIS : - The coal gasification for the synthetic gas needs high temperature reaction more than $1,100^{\circ} \mathrm{C}$. But at that high temperature, the ash in the coal is shown complicate behavior from soild phase to liquid phase.

The authors are considered on the behavior of the ash at high temperature in this paper.

As rising the ash temperature, first, the compounds in the ash which has low melting points, begin to melt and to show sticky property.

Next, the ash is change to slurry, and last, melt all over the ash and change to liquid phase.

When add some $\mathrm{CaO}$ to the ash, the melting point of the ash is more higher than the original ash. When add some $\mathrm{Fe}_{2} \mathrm{O}_{3}$, liquidus slag viscosity of the ash is down remarkably.

\section{Key Words}

Coal gasification, Ash, Melting points, $\mathrm{CaO}, \mathrm{Fe}_{2} \mathrm{O}_{3}$

\section{あとがき}

本小特集号を計画するに当っては，全体の取りをとめを東京ガス秼 片岡宏文常務取締役に お願いした。

また各原稿の執筆については下記の方々のご討論, ご協力をいただいている。これらの方々 に潹く感謝する次第である。

$\begin{array}{lll}\text { 岡部 明 (三菱重工) } & \text { 原 } & \text { 辰夫（川崎重工） } \\ \text { 佐久間精一 (日揮) } & \text { 松浦 } & \text { 庸夫 (宇部興産) } \\ \text { 冨田 忠義 }(\text { T E C ) } & \text { 山本 } & \text { 洋平（東京ガス） }\end{array}$

